LETTER

\section{Characteristics of ischaemic stroke associated with COVID-19}

Coronavirus disease 2019 (COVID$19)$, caused by severe acute respiratory syndrome coronavirus 2 (SARS-CoV-2) infection, is associated with coagulopathy causing venous and arterial thrombosis. ${ }^{12}$ Recent data from the pandemic epicentre in Wuhan, China, reported neurological complications in $36 \%$ of 214 patients with COVID-19; acute cerebrovascular disease (mainly ischaemic stroke) was more common among 88 patients with severe COVID-19 than those with nonsevere disease $(5.7 \%$ vs $0.8 \%){ }^{3}$ However, the mechanisms, phenotype and optimal management of ischaemic stroke associated with COVID-19 remain uncertain. We describe the demographic, clinical, radiological and laboratory characteristics of six consecutive patients assessed between $1^{\text {st }}$ and $16^{\text {th }}$ April 2020 at the National Hospital for Neurology and Neurosurgery, Queen Square, London, UK, with acute ischaemic stroke and COVID-19 (confirmed by reverse-transcriptase PCR (RT-PCR)) (table 1). All six patients had large vessel occlusion with markedly elevated D-dimer levels $(\geq 1000 \mu \mathrm{g} / \mathrm{L})$. Three patients had multiterritory infarcts, two had concurrent venous thrombosis, and, in two, ischaemic strokes occurred despite therapeutic anticoagulation.

\section{PATIENT 1}

A 64-year-old man presented 10 days after COVID-19 symptom onset (cough, breathlessness, fever, myalgia and poor appetite), with respiratory failure warranting intensive care unit admission. Mycoplasma pneumoniae infection was treated with clarithromycin. On day 15, he developed mild left arm weakness and incoordination. MRI confirmed intradural left vertebral artery occlusion and acute left posterior inferior cerebellar artery territory infarction with petechial haemorrhage (online supplementary figure S1A). D-dimer was $>80000 \mu \mathrm{g} / \mathrm{L}$. He received aspirin and clopidogrel. On day 19 , he developed bilateral pulmonary embolism, treated with therapeutic low molecular weight heparin (LMWH). On day 22, he developed acute bilateral incoordination and right homonymous hemianopia; MRI brain showed extensive acute posterior cerebral artery territory infarction (online supplementary figure $\mathrm{S} 1 \mathrm{~B}$ ); he received high-intensity LMWH anticoagulation.

\section{PATIENT 2}

A 53-year-old woman, taking warfarin for valvular atrial fibrillation (AF), presented 24 days after COVID-19 symptom onset (cough, dyspnoea), with acute confusion, incoordination and drowsiness; CT brain confirmed acute large left cerebellar and right parieto-occipital infarcts (online supplementary figure S1 C, D). D-dimer was $7750 \mu \mathrm{g} / \mathrm{L}$, and the International Normalised Ratio (INR) 3.6 at the time of stroke symptoms. Following external ventricular drainage for hydrocephalus she was given therapeutic LMWH anticoagulation. She died following cardiorespiratory deterioration due to COVID-19 pneumonia.

\section{PATIENT 3}

An 85-year-old man presented 10 days after COVID-19 symptom onset with dysarthria and right hemiparesis. He had $\mathrm{AF}$, hypertension and ischaemic heart disease. CT brain showed left posterior cerebral artery occlusion and infarction (online supplementary figure S1 E, F). D-dimer was $16100 \mu \mathrm{g} / \mathrm{L}$. He was treated with apixaban for AF secondary prevention.

\section{PATIENT 4}

A 61-year-old man with hypertension, previous stroke and high body mass index presented with dysarthria and left hemiparesis. MRI brain showed an acute right striatal infarct (online supplementary figure S1 G, H). D-dimer was $27190 \mu \mathrm{g} / \mathrm{L}$. Two days following admission, he developed respiratory symptoms. RT-PCR confirmed SARS-CoV-2 infection and CT pulmonary angiogram an embolus. He was treated with therapeutic LMWH.

\section{PATIENT 5}

An 83-year-old man with a history of hypertension, diabetes, ischaemic heart disease, heavy smoking and alcohol consumption, presented with dysarthria and left hemiparesis 15 days after COVID-19 symptom onset. CT angiogram showed thrombotic occlusion of a proximal M2 branch of the right middle cerebral artery (online supplementary figure S2 A); the following day an infarct was shown in the right insula (online supplementary figure S2B). D-dimer was
$19450 \mu \mathrm{g} / \mathrm{L}$. He was treated with intravenous thrombolysis.

\section{PATIENT 6}

A 73-year-old man presented, 8 days after COVID-19 symptom onset, with dysphasia and right hemiparesis. MRI brain showed a thrombus in the basilar artery, bilateral P2 segment stenosis and multiple acute infarcts (right thalamus, left pons, right occipital lobe and right cerebellar hemisphere) (online supplementary figure S2 C, D, E, F). $\mathrm{He}$ received intravenous thrombolysis, after which D-dimer was $1080 \mu \mathrm{g} / \mathrm{L}$.

\section{DISCUSSION}

SARS-CoV-2infection is linked to a prothrombotic state causing venous and arterial thromboembolism and elevated D-dimer levels. ${ }^{2}$ Severe COVID-19 is associated with proinflammatory cytokines which induce endothelial and mononuclear cell activation with expression of tissue factor leading to coagulation activation and thrombin generation. Circulation of free thrombin, uncontrolled by natural anticoagulants, can activate platelets and lead to thrombosis. ${ }^{2}$ Although ischaemic stroke has been recognised as a complication of COVID-19 (usually with severe disease), ${ }^{3}$ the mechanisms and phenotype are not yet understood. Our observations suggest that acute ischaemic stroke accompanying COVID-19 infection may have distinct characteristics, with implications for diagnosis and treatment. All patients had large-vessel occlusion; in three these were in multiple territories. In two patients ( 1 and 2 ) one recurrent stroke and one initial ischaemic stroke, respectively, occurred despite therapeutic anticoagulation. Two patients had concurrent venous thromboembolism. Five patients had very high D-dimer levels (>7000 $\mu \mathrm{g} / \mathrm{L})$, substantially higher than the median level reported in COVID-19 $(900 \mu \mathrm{g} / \mathrm{L}) ;^{3}$ the D-dimer for patient 6 was $1080 \mu \mathrm{g} / \mathrm{L}$ after intravenous thrombolysis. In five of six patients, ischaemic stroke occurred 8-24 days after COVID-19 symptom onset, and in one patient during the presymptomatic phase, suggesting that COVID-19 associated ischaemic stroke is usually delayed, but can occur both early and later in the course of the disease.

It has been suggested that COVID-19 might stimulate the production of antiphospholipid antibodies $(\mathrm{aPL})^{4}$ as a mechanism of ischaemic stroke, although postinfection aPL are usually transient and unassociated with thrombosis. Five 
PostScript

Table 1 Demographic, clinical, radiological and laboratory findings

\begin{tabular}{|c|c|c|c|c|c|c|}
\hline & Patient 1 & Patient 2 & Patient 3 & Patient 4 & Patient 5 & Patient 6 \\
\hline \multicolumn{7}{|l|}{ Demographic characteristics } \\
\hline Age, years & 64 & 53 & 85 & 61 & 83 & 73 \\
\hline Sex & Male & Female & Male & Male & Male & Male \\
\hline Medical history & Nil & $\begin{array}{l}\text { Hypertension, diabetes, mitral } \\
\text { valve replacement, atrial } \\
\text { fibrillation, heart failure with a } \\
\text { permanent pacemaker }\end{array}$ & $\begin{array}{l}\text { Hypertension, } \\
\text { hypercholesterolaemia, atrial } \\
\text { fibrillation, ischaemic heart } \\
\text { disease, prostate cancer } \\
\text { (Gleason Score 4+5) }\end{array}$ & $\begin{array}{l}\text { Hypertension, stroke, chronic } \\
\text { leg ulcers }\end{array}$ & $\begin{array}{l}\text { Hypertension, diabetes, } \\
\text { ischaemic heart disease, } \\
\text { smoking and alcohol } \\
\text { consumption }\end{array}$ & $\begin{array}{l}\text { Gastric carcinoma (resected), } \\
\text { benign essential tremor }\end{array}$ \\
\hline Symptoms at COVID-19 disease onset & $\begin{array}{l}\text { Cough, shortness of breath, } \\
\text { fever, myalgia, loss of appetite }\end{array}$ & $\begin{array}{l}\text { Malaise, dry cough, shortness } \\
\text { of breath, fever }\end{array}$ & Cough & $\begin{array}{l}\text { Fever, cough, shortness of } \\
\text { breath, tachypnoea }\end{array}$ & $\begin{array}{l}\text { Fever, cough, shortness of } \\
\text { breath, fatigue }\end{array}$ & $\begin{array}{l}\text { Shortness of breath, } \\
\text { tachypnoea }\end{array}$ \\
\hline Initial treatment & Antibiotics, oxygen therapy & Supportive & Supportive & Antibiotics & Antibiotics, oxygen therapy & Antibiotics, oxygen therapy \\
\hline $\begin{array}{l}\text { Days from COVID-19 symptom onset to } \\
\text { ischaemic stroke symptom onset }\end{array}$ & 15 & 24 & 10 & $\begin{array}{l}-2 \text { (stroke preceded COVID-19 } \\
\text { symptoms by } 2 \text { days) }\end{array}$ & 15 & 8 \\
\hline Clinical symptoms of ischaemic stroke & $\begin{array}{l}\text { Word-finding difficulties, } \\
\text { bilateral incoordination, right } \\
\text { homonymous hemianopia }\end{array}$ & $\begin{array}{l}\text { Acute confusion, } \\
\text { incoordination, reduced } \\
\text { consciousness } \\
\text { (GCS 13/15) }\end{array}$ & $\begin{array}{l}\text { Dysarthria, right facial droop } \\
\text { and right-sided weakness }\end{array}$ & $\begin{array}{l}\text { Dysarthria, left facial droop and } \\
\text { left-sided weakness }\end{array}$ & $\begin{array}{l}\text { Dysarthria, left facial droop, } \\
\text { left-sided weakness and left- } \\
\text { sided sensory inattention }\end{array}$ & $\begin{array}{l}\text { Aphasia, right facial droop and } \\
\text { right-sided weakness }\end{array}$ \\
\hline \multicolumn{7}{|l|}{ ICU admission and disease severity } \\
\hline $\begin{array}{l}\text { Days from COVID-19 symptom onset to } \\
\text { ICU admission }\end{array}$ & 14 & 25 & $\begin{array}{l}\text { Did not go to } \\
\text { ICU }\end{array}$ & Did not go to ICU & Did not go to ICU & Did not go to ICU \\
\hline COVID-19 disease severity & Severe & Critical & Moderate to severe & Moderate & Severe & Severe \\
\hline \multicolumn{7}{|c|}{ Laboratory findings on the day of first or only ischaemic stroke event } \\
\hline Haemoglobin (g/L) & $119 \downarrow$ & $94 \downarrow$ & $128 \downarrow$ & $126 \downarrow$ & $121 \downarrow$ & 142 \\
\hline White cell count $\left(/ \mathrm{mm}^{3}\right)$ & 6750 & $23050 \uparrow$ & 5080 & 8970 & $11030 \uparrow$ & 7300 \\
\hline \multicolumn{7}{|l|}{ Differential count $\left(/ \mathrm{mm}^{3}\right)$} \\
\hline Neutrophils & 5810 & $19200 \uparrow$ & 4440 & 6390 & $8330 \uparrow$ & 5800 \\
\hline Lymphocytes & $470 \downarrow$ & 2070 & $402 \downarrow$ & 1310 & 1630 & $890 \downarrow$ \\
\hline Monocytes & 370 & $1660 \uparrow$ & $180 \downarrow$ & 900 & 830 & 470 \\
\hline Platelet count $\left(/ \mathrm{mm}^{3}\right)$ & 305000 & 254000 & 173000 & $408000 \uparrow$ & 197000 & $403000 \uparrow$ \\
\hline Albumin $(\mathrm{g} / \mathrm{L})$ & $28 \downarrow$ & $28 \downarrow$ & $33 \downarrow$ & $31 \downarrow$ & $32 \downarrow$ & $32 \downarrow$ \\
\hline Alanine aminotransferase (U/L) & $137 \uparrow$ & 27 & 32 & 24 & 37 & $75 \uparrow$ \\
\hline Bilirubin ( $\mu \mathrm{mol} / \mathrm{L})$ & 11 & $29 \uparrow$ & 17 & 13 & 11 & 10 \\
\hline Lactate dehydrogenase (U/L) & $654 \uparrow$ & $664 \uparrow$ & $461 \uparrow$ & $444 \uparrow$ & $353 \uparrow$ & $439 \uparrow$ \\
\hline Creatinine $(\mu \mathrm{mol} / \mathrm{L})$ & 57 & 75 & 77 & 107 & 100 & 68 \\
\hline $\operatorname{EGFR}\left(\mathrm{m} / / \mathrm{min} / 1.73 \mathrm{~m}^{2}\right)$ & $>90$ & 74 & 87 & 63 & 64 & $>90$ \\
\hline High-sensitivity cardiac troponin I (pg/ml) & 9 & $42 \uparrow$ & $32 \uparrow$ & $30 \uparrow$ & $66 \uparrow$ & 8 \\
\hline Prothrombin time (s) & $12.5 \uparrow$ & $34.4 \uparrow$ & 11.3 & 10.9 & 11.7 & $12.3 \uparrow$ \\
\hline International normalised ratio (INR) & 1.14 & $3.6 \uparrow^{*}$ & 1.03 & 0.99 & 1.07 & 1.13 \\
\hline $\begin{array}{l}\text { Activated partial-thromboplastin time } \\
\text { (APPT) (s) }\end{array}$ & 35 & $41 \uparrow *$ & 33 & $24 \downarrow$ & 30 & 32 \\
\hline APPT ratio & 1.1 & $1.3 \uparrow$ & 1 & 0.8 & 1.0 & 1 \\
\hline Fibrinogen (g/L) & $9.5 \uparrow$ & 7.03 & $5.3 \uparrow$ & $4.63 \uparrow$ & $4.96 \uparrow$ & - \\
\hline D-dimer $(\mu \mathrm{g} / \mathrm{L})$ & $>80000 \uparrow$ & $7750 \uparrow$ & $16100 \uparrow$ & $27190 \uparrow$ & $19450 \uparrow$ & $1080 \uparrow$ \\
\hline Serum ferritin $(\mu \mathrm{g} / \mathrm{L})$ & $4927 \uparrow$ & $1853 \uparrow$ & $1027 \uparrow$ & $1167 \uparrow$ & & $655 \uparrow$ \\
\hline High-sensitivity C reactive protein (mg/L) & $305.4 \uparrow$ & $150.1 \uparrow$ & $161.2 \uparrow$ & 12.8 & $27.7 \uparrow$ & $179.9 \uparrow$ \\
\hline $\begin{array}{l}\text { Antiphospholipid antibodies: } \\
\text { Anticardiolipin (aCL) } \\
\text { Anti-ß2-glycoprotein-1 (aß2GPI) }\end{array}$ & $\begin{array}{l}\text { Medium titre } \operatorname{lgM} \text { aCL } \\
\lg \mathrm{aCL} \text { negative } \\
\text { Low titre } \operatorname{lgG} \text { and IgM aß2GP1 }\end{array}$ & $\begin{array}{l}\lg \mathrm{G} \text { and } \operatorname{lgM} \mathrm{aCL} \text { and } \mathrm{a} \beta 2 \mathrm{GP} 1 \\
\text { negative }\end{array}$ & $\begin{array}{l}\operatorname{lgG} \text { and } \operatorname{lgM} \text { aCL } \\
\text { and a } \beta 2 \mathrm{GP1} \\
\text { negative }\end{array}$ & $\begin{array}{l}\lg \mathrm{G} \text { and } \operatorname{lgM} \mathrm{aCl} \text { and } \mathrm{a} \beta 2 \mathrm{GP1} \\
\text { negative }\end{array}$ & $\begin{array}{l}\text { IgG and IgM aCL and aß2GP1 } \\
\text { negative }\end{array}$ & $\begin{array}{l}\lg \mathrm{G} \text { and } \operatorname{lgM} \mathrm{aCL} \text { and aß2GP1 } \\
\text { negative }\end{array}$ \\
\hline Lupus anticoagulant & Positive & Positive & Negative & Positive & Positive & Positive \\
\hline \multicolumn{7}{|l|}{ Imaging features } \\
\hline $\begin{array}{l}\text { Brain } \\
\text { (online supplementary figures } \mathrm{S} 1 \text { and } \mathrm{S} 2 \text { ) }\end{array}$ & $\begin{array}{l}\text { MRI including diffusion- } \\
\text { weighted and susceptibility- } \\
\text { weighted imaging showed } \\
\text { acute left vertebral artery } \\
\text { thrombus and acute left } \\
\text { posterior-inferior cerebellar } \\
\text { artery territory infarction } \\
\text { with petechial haemorrhagic } \\
\text { transformation. } 7 \text { days } \\
\text { later, diffusion-weighted } \\
\text { MRI showed bilateral acute } \\
\text { posterior cerebral artery } \\
\text { territory infarcts despite } \\
\text { therapeutic anticoagulation }\end{array}$ & $\begin{array}{l}\text { Non-contrast CT showed acute } \\
\text { right parietal cortical and left } \\
\text { cerebellar infarct with mass } \\
\text { effect and hydrocephalus, } \\
\text { despite therapeutic } \\
\text { anticoagulation }\end{array}$ & $\begin{array}{l}\text { Non-contrast CT showed } \\
\text { hyperdensity consistent with } \\
\text { thrombus in the left posterior } \\
\text { cerebral artery and acute } \\
\text { infarction in the left temporal } \\
\text { stem and cerebral peduncle }\end{array}$ & $\begin{array}{l}\text { Diffusion-weighted MRI } \\
\text { showed acute infarction in } \\
\text { the right corpus striatum } \\
\text { suggesting transient occlusion } \\
\text { of the M1 segment of the right } \\
\text { middle cerebral artery; fluid } \\
\text { attenuated inversion recovery } \\
\text { MRI showed an established } \\
\text { infarct in the same region with } \\
\text { moderate background cerebral } \\
\text { small vessel disease }\end{array}$ & $\begin{array}{l}\mathrm{CT} \text { and } \mathrm{CT} \text { angiogram showed } \\
\text { thrombotic occlusion of a } \\
\text { proximal M2 branch of the } \\
\text { right middle cerebral artery; a } \\
\text { repeat } \mathrm{CT} \text { at } 24 \text { hours showed } \\
\text { a focus of parenchymal low } \\
\text { density involving the right } \\
\text { insular cortex in keeping } \\
\text { with an evolving right middle } \\
\text { cerebral artery territory infarct }\end{array}$ & $\begin{array}{l}\text { Diffusion-weighted MRI } \\
\text { showed acute infarction } \\
\text { in the right thalamus, left } \\
\text { pons, right occipital lobe and } \\
\text { right cerebellar hemisphere. } \\
\text { Time-of-flight images showed } \\
\text { thrombotic material in the } \\
\text { basilar artery and bilateral } \\
\text { mild-to-moderate P2 segment } \\
\text { stenosis }\end{array}$ \\
\hline Chest & $\begin{array}{l}\text { Chest X-ray: Bilateral } \\
\text { pulmonary infiltrates } \\
\text { CT pulmonary angiogram: } \\
\text { Bilateral pulmonary embolism; } \\
\text { semiocclusive right middle lobe } \\
\text { segmental and right lower lobe } \\
\text { subsegmental, non-occlusive } \\
\text { lower lobe subsegmental } \\
\text { embolus }\end{array}$ & $\begin{array}{l}\text { CT chest: Bilateral ground-glass } \\
\text { change and consolidation } \\
\text { CT pulmonary angiogram: } \\
\text { No large pulmonary embolus } \\
\text { within the main or segmental } \\
\text { pulmonary arteries }\end{array}$ & $\begin{array}{l}\text { Chest X-ray: Bilateral peripheral } \\
\text { airspace opacities throughout } \\
\text { both lungs, worse on the right }\end{array}$ & $\begin{array}{l}\text { CT chest: Bilateral patchy } \\
\text { subpleural airspace } \\
\text { opacification in both lungs } \\
\text { CT pulmonary angiogram: } \\
\text { Pulmonary embolus in the left } \\
\text { upper lobe segmental artery }\end{array}$ & $\begin{array}{l}\text { Chest X-ray: few ill-defined } \\
\text { patchy airspace opacifications } \\
\text { seen peripherally in both lung } \\
\text { fields mid-zones and lower } \\
\text { zones, mild amount right-sided } \\
\text { pleural effusion. } \\
\text { CT pulmonary angiogram: } \\
\text { No large pulmonary embolus } \\
\text { within the main or segmental } \\
\text { pulmonary arteries }\end{array}$ & $\begin{array}{l}\text { Chest X-ray: Bilateral } \\
\text { predominantly peripheral } \\
\text { airspace opacities, most } \\
\text { confluent at the mid-zones and } \\
\text { the lung bases } \\
\text { CT pulmonary angiogram: } \\
\text { No large pulmonary embolus } \\
\text { within the main or segmental } \\
\text { pulmonary arteries }\end{array}$ \\
\hline Other vascular imaging & $\begin{array}{l}\text { Lower limb Doppler ultrasound: } \\
\text { occlusive DVT in the left } \\
\text { posterior tibial vein and the left } \\
\text { peroneal vein }\end{array}$ & & & & & \\
\hline
\end{tabular}

*Patient taking warfarin.
DVT, Deep Vein Thrombosis ; EGFR, Estimated Glomerular Filtration Rate; GCS, Glasgow Coma Score ; ICU, intensive care unit. 
of six patients had a positive lupus anticoagulant, one with medium-titre IgM anticardiolipin and low-titre $\operatorname{IgG}$ and IgM anti- $\beta 2$-glycoprotein- 1 antibodies. Screening for aPL might be reasonable in patients with COVID-19 associated ischaemic stroke, although their pathogenic relevance remains uncertain. All patients had elevated ferritin and lactate dehydrogenase levels, both of which have been reported in severe COVID-19. ${ }^{1}$

Our data cannot confirm a causal relationship between SARS-CoV-2 and ischaemic stroke, since competing vascular risk factors and mechanisms were present in most patients (table 1); four of six had hypertension, and two had AF. It is also possible that the effects of social distancing measures and anxiety about attending hospital might have influenced the spectrum of ischaemic stroke mechanisms in patients seen at our hospital.

Nevertheless, our findings suggest that ischaemic stroke linked to COVID-19 infection can occur in the context of a systemic highly prothrombotic state, supporting recommendations for immediate prophylactic anticoagulation with LMWH. ${ }^{5}$ Early therapeutic anticoagulation with LMWH could also be beneficial to reduce thromboembolism in patients with COVID-19associated ischaemic stroke but must be balanced against the risk of intracranial haemorrhage, including haemorrhagic transformation of the acute infarct; clinical trials are warranted to determine the safety and efficacy of this approach.

\footnotetext{
Rahma Beyrouti, ${ }^{1}$ Matthew E Adams, ${ }^{2}$

Laura Benjamin, ${ }^{3,4}$ Hannah Cohen,

Simon F Farmer, ${ }^{6}$ Yee Yen Goh,

Fiona Humphries, ${ }^{1}$ Hans Rolf Jäger, ${ }^{2,7}$

Nicholas A Losseff, ${ }^{1,8}$ Richard J Perry, ${ }^{1,4}$

Sachit Shah, ${ }^{2}$ Robert J Simister, ${ }^{1,4}$ David Turner, ${ }^{1}$

Arvind Chandratheva, ${ }^{1,4}$ David J Werring (1,4

${ }^{1}$ Comprehensive Stroke Service, University College London Hospitals NHS Foundation Trust, London, UK ${ }^{2}$ Lysholm Department of Neuroradiology, University College London Hospitals NHS Foundation Trust National Hospital for Neurology and Neurosurgery, London, UK
}

${ }^{3}$ Brain Infections Group, Institute of Infection and Global Health, University of Liverpool, Liverpool, UK ${ }^{4}$ Stroke Research Centre, UCL Queen Square Institute of Neurology, London, UK

${ }^{5}$ Hemostasis Research Unit, Department of Hematology, University College London, London, UK

${ }^{6}$ Department of Neurology, University College London Hospitals NHS Foundation Trust National Hospital for Neurology and Neurosurgery, London, UK ${ }^{7}$ Department of Brain Repair and Rehabilitation, University College London Queen Square Institute of Neurology, London, UK

${ }^{8}$ Cleveland Clinic, Grosvenor Place, London SW1 X7HY, United Kingdom

Correspondence to Professor David J Werring, Stroke Research Centre, UCL Queen Square Institute of Neurology, London WC1B 5EH, UK; d.werring@ucl. ac.uk

Correction notice This paper has been corrected since it was published Online First. The following standard funding statement has been added, along with minor formatting changes. "This work was undertaken at UCLH/UCL which receives a proportion of funding from the Department of Health's National Institute for Health Research (NIHR) Biomedical Research Centres funding scheme."

Contributors DJW and AC had the idea for the paper. RB prepared the first draft with DJW and AC. DJW prepared the draft figures. MEA and SS assisted with imaging interpretation and critically reviewed the manuscript for intellectual content. AC, DJW, RB, HC, SFF, YYG, FH, RJS, DT, NAL and RJP were involved in the clinical care of the patients and critically reviewed the manuscript for intellectual content. HRJ assisted with imaging interpretation and preparation of the figures, and critically reviewed the manuscript for intellectual content.

Funding This work was undertaken at UCLH/UCL which receives a proportion of funding from the Department of Health's National Institute for Health Research (NIHR) Biomedical Research Centres funding scheme.

Competing interests DJW has received personal fees from Bayer, Alnylam and Portola, outside the submitted work

Patient consent for publication Obtained.

Provenance and peer review Not commissioned; internally peer reviewed.

\section{(2) \\ OPEN ACCESS}

Open access This is an open access article distributed in accordance with the Creative Commons Attribution
Non Commercial (CC BY-NC 4.0) license, which permits others to distribute, remix, adapt, build upon this work non-commercially, and license their derivative works on different terms, provided the original work is properly cited, appropriate credit is given, any changes made indicated, and the use is non-commercial. See: http:// creativecommons.org/licenses/by-nc/4.0/.

(c) Author(s) (or their employer(s)) 2020. Re-use permitted under CC BY-NC. No commercial re-use. See rights and permissions. Published by BMJ.

- Additional material is published online only. To view please visit the journal online (http://dx.doi.org/ 10.1136/jnnp-2020-323586).

$A C$ and DJW contributed equally.

$$
\text { Check for updates }
$$

To cite Beyrouti R, Adams ME, Benjamin L, et al. J Neurol Neurosurg Psychiatry 2020;91:889-891.

Received 24 April 2020

Accepted 27 April 2020

Published Online First 30 April 2020

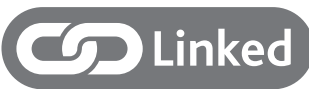

- http://dx.doi.org/10.1136/jnnp-2020-323667

J Neurol Neurosurg Psychiatry 2020;91:889-891. doi:10.1136/jnnp-2020-323586

ORCID iD

David J Werring http://orcid.org/0000-0003-20741861

\section{REFERENCES}

1 Chen N, Zhou M, Dong X, et al. Epidemiological and clinical characteristics of 99 cases of 2019 novel coronavirus pneumonia in Wuhan, China: a descriptive study. The Lancet 2020;395:507-13.

2 Tang N, Li D, Wang X, et al. Abnormal coagulation parameters are associated with poor prognosis in patients with novel coronavirus pneumonia. J Thromb Haemost 2020;18:844-7.

3 Mao L, Jin H, Wang M, et al. Neurologic manifestations of hospitalized patients with coronavirus disease 2019 in Wuhan, China. JAMA Neurol 2020 (published Online First: 2020/04/11).

4 Zhang Y, Xiao M, Zhang S, et al. Coagulopathy and antiphospholipid antibodies in patients with Covid-19. N Engl J Med 2020 (published Online First: 2020/04/09).

5 Thachil J, Tang N, Gando S, et al. ISTH interim guidance on recognition and management of coagulopathy in COVID-19. Journal of Thrombosis and Haemostasis;n/ $a(n / a)$. 